\title{
As narrativas orais e o imaginário das crianças ribeirinhas
}

\author{
Oral narratives and the imagination of riverside children
}

Maria do Socorro Galvão Simões

Universidade Federal do Pará (UFPA)

Cristiane do Socorro Gonçalves Farias

Universidade Federal do Pará (UFPA)

Resumo: Este artigo busca suprir uma lacuna na produção acadêmica, haja vista a escassez de trabalhos abordando a temática sob o ângulo do narrador infantil. Porém, para isso, faz-se necessário o trabalho da escuta por parte destas pesquisadoras. Para tanto, trazemos uma narrativa de Cobra Grande e outra do Boto contada por uma criança ribeirinha do rio Canaticu, em Curralinho, na Ilha do Marajó. Nesse percurso, buscamos amparo nas leituras de Zumthor (1993) para entendermos as narrativas de tradição oral, Benjamin (1993) para (re)conhecermos nas crianças a figura de um narrador tradicional e Bachelard (2006) para discutirmos o imaginário.

Palavras-chave: Narrativa oral. Crianças ribeirinhas. Imaginário.

\begin{abstract}
This article seeks to fill a gap in academic production given the scarcity of works addressing the theme from the angle of the child narrator. However, for this, it is necessary the work of listening on the part of these researchers. To do so, we bring a narrative of Cobra Grande and another of Boto told by a river child of the river Canaticu, in Curralinho, on the Island of Marajó. A long the process, we searched for help in Zumthor's publications (1993), for a better understanding about oral tradition-based narratives. Benjamim (1993) to recognize on the children a traditional-style narrative, and Bachelard (2006), to reflect the imagination.
\end{abstract}

Key-words: Oral narrative. Children. Imagination. 


\section{Introdução}

Esse rio é minha rua

Minha e tua, mururé

Maria do

Piso no peito da lua

Socorro Galvão

Deito no chão da maré

Simões

Cristiane

Pois é, pois é

do Socorro

Eu não sou de igarapé

Gonçalves

Quem montou na cobra grande

Não se escancha em poraqué.

Farias

Ruy Barata

110 O trabalho poderia iniciar-se com outra epígrafe, no entanto, talvez não tivesse a mesma representatividade da liquidez do sujeito amazônico, do quanto as águas estão em nossas entranhas. Essa é uma característica tão singular que literalmente temos nos rios nossas ruas, horizontes. Talvez não saberíamos viver de outro jeito, senão por essas ruas e rios onde dividimos espaço com o outro, seja cobra, boto, florestas, furos e igarapés. Como um conjunto, a paisagem aqui "é contemplada pelo caboclo como uma dupla realidade: imediata e mediata. A imediata de função material, lógica, objetiva. A mediata de função mágica, encantatória, estética" (LOUREIRO, 1995, p. 132).

Os ribeirinhos são embalados por essa movência do espaço, ou seja, os rios e as matas nos ensinam sobre tudo, principalmente sobre o tempo: o tempo das águas, o tempo das roças, o tempo da colheita, o tempo das seringueiras, o tempo da viagem, o tempo das sementes e, por fim, o tempo de lembrar e de contar, dessa forma, "o miraculoso relógio da Amazônia é a água" (MORAIS, p. 257).

Para Loureiro (1995, p. 121), “a vida social articula-se em tomo de uma linguagem poética anterior aos tempos históricos, que flui tão naturalmente como os fluxos que têm as águas de um regato". Articula-se também na interpenetração desses com a paisagem, uma relação que busca o devir, não só para a sua sobrevivência como sujeito que vive o espaço, mas para o Homem que acredita em algo que não lhe é palpável, e continua, "o olhar não se confina no que vê. 0 olhar, através do que vê, vê o que não vê. Isto é, contempla uma realidade visual que ultrapassa os sentidos práticos e penetra numa outra margem do real" (p. 132). 
Índios, negros, caboclos, ribeirinhos, seringueiros, roceiros, homens, mulheres, velhos e crianças, em sua maioria, nascem banhados por água, crescem e aprendem com a natureza, com a maré enchente e vazante, maré essa que leva e traz canoas, pessoas, mururés, lembranças, alegrias, tristezas, esperanças e, por fim, histórias submersas nas memórias que se entrelaçam ao cotidiano, mostrando-nos a profundidade do imaginário, onde, por vezes, se revolta com a própria realidade, outras, revela-se um olhar calmo, sensível, ou melhor, "procuram explicar o que não conhecem, descobrindo o mundo pelo estranhamento, alimentando o desejo de conhecer e desvendar o sentido das coisas ao seu redor" (LOUREIRO, 1995, p. 121).

Essa linguagem poética de que fala Loureiro nos remete aqui ao ato poético de saber contar algo, narrar. Houve um tempo em que

As narrativas orais eo imaginário das crianças ribeirinhas a voz tinha uma supremacia em relação à escrita. Isso era a época em que a tradição oral desempenhava um papel importante no caminhar da humanidade. Para Zumthor (2010, p. 10), era o instante da criação, "o sopro da voz é criador", o momento da aprendizagem, ou seja, criava-se um elo entre gerações, em que costumes, saberes, fazeres eram transmitidos. A voz em forma de narrativa e gesto, que alcança os ouvidos do espectador como gotas de remédio para acalantar um estado de espírito, como podemos entender em Conto $e$ cura de Walter Benjamin.

Ao falarmos em voz, corpo e narrativa, falamos em um sujeito que toma a forma de narrador da tradição oral. Walter Benjamim, filósofo alemão, nos aponta dois tipos de narradores: o viajante e o agricultor. O viajante sai e, a partir das suas vivências, experiências adquiridas, retorna com as bagagens cheias de histórias de fatos, "quem viaja tem muito o que contar", e o narrador que fica em seu lugar igualmente tem experiências para contar, "também escutamos com prazer o homem que ganhou honestamente sua vida sem sair do país" (BENJAMIN, 1993, p. 198).

A figura do narrador, em sua maioria, cabe ao velho, por conta dos saberes adquiridos a partir de sua vivência. Infelizmente, para muitos, a conversa, o diálogo com um idoso é muito raro, pois o tempo de um adulto jovem é diferente do tempo do idoso. $O$ adulto em plena atividade de trabalho não tem o tempo da escuta, como indica Ecléa Bosi (1994, p. 60): "para o adulto ativo, vida prática é vida prática, e memória é fuga, arte, lazer, contemplação". 
Conforme Benjamin (1993, p. 221), “o narrador figura entre os mestres e sábios", em sua maioria, a imagem do narrador é direcionada ao velho de uma comunidade, pois é ele quem adquiriu uma vasta expe-

Maria do

Socorro Galvão

Simões

Cristiane

do Socorro

Gonçalves

Farias riência durante toda a vida. Porém, esse narrador necessita de alguém para ouvi-lo, e qualquer pessoa que possa lhe oferecer um pouco de atenção se torna um ávido ouvinte, e então a narrativa surge, em qualquer espaço, na ponte de frente para o rio, na casa de farinha, na canoa, em frente das casas, em qualquer lugar onde se provoque esse narrador.

Quanto ao ouvinte, Benjamin destaca (1993, p. 205-213): “quanto mais o ouvinte se esquece de si mesmo, mais profundamente se grava nele o que é ouvido [...], quem escuta uma história está em companhia do narrador". Isto é: a tarefa de ouvir produz um recomeço. Como salienta também Zumthor (2010), há no ouvinte a possibilidade da existência de dois "papéis": o papel de "receptor" e o de "coautor" (p. 258), que dependem da interação entre pessoas, da ação comunicativa:

\footnotetext{
O componente fundamental da "recepção" é assim a ação do ouvinte, recriando, de acordo com seu próprio uso e suas próprias configurações interiores, o universo significante que lhe é transmitido. As marcas que esta re-criação imprime nele pertencem a sua vida íntima e não se exteriorizam necessária e imediatamente. Mas pode ocorrer que elas se exteriorizem em nova performance: o ouvinte torna-se por seu turno intérprete, e, em sua boca, em seu gesto, o poema se modifica de forma, quem sabe, radical (ZUMTHOR, 2010, p. 258).
}

Walter Benjamin já bem percebia isso, por mais que constatasse um declínio na ação de narrar no contexto em que vivia ${ }^{1}$. Destacava o papel essencial do ouvinte e da memória deste: "não se percebeu devidamente até agora que a relação ingênua entre o ouvinte e o narrador é dominada pelo interesse em conservar o que foi narrado. Para o ouvinte imparcial o importante é assegurar a possibilidade de reprodução”. Outrossim, “A memória é a capacidade épica” (BENJAMIN, 1993, p. 210-215).

\footnotetext{
1 Refere-se às catastróficas e traumáticas guerras do século XX, de onde os soldados voltavam calados e introspectivos. Acresce que as pessoas as quais eram submetidas àquele horror não faziam questão de lembrar do que haviam experienciado, naturalmente não faziam questão de contar, pois essas memórias lhes eram dolorosas.
} 
Partindo desse pressuposto, a reflexão aqui é essa "relação ingênua" que impulsiona para a busca do ouvinte que tem, a partir da memória da "coisa narrada", a possibilidade do reconto, como nos indica Benjamin: "contar histórias sempre foi a arte de contá-las de novo" (Ibidem, p. 205), e da "co-autoria", como nos orienta Zumthor (2010). Por isso, percebemos na criança mais um tipo de narrador, ou melhor, um sujeito aprendiz na tradição do narrar. Dessa forma, desviamos o olhar do velho narrador tradicional de que fala Benjamin para outros narradores, nem tão ouvidos quanto os velhos, mas igualmente importantes: vamos ao encontro das crianças ribeirinhas marajoaras.

\section{Criança: narradora aprendiz}

O ser humano é inserido precocemente no mundo das histórias, e essa precocidade pode advir da nossa predisposição pela narrativa que é entranhada em nossas experiências neste mundo. Desde o início dos tempos, conseguimos externar formas de narrar o que nos afeta. Por meio da história sobre o desenvolvimento do Homem, dos estudos que objetivavam desvendar os mistérios sobre nossos antepassados, é que conseguimos entender como a narrativa é algo essencial para a vida na Terra.

Desde os tempos primórdios, já sentíamos a necessidade de contar sobre algo, sobre o nosso trabalho, nossas relações, enfim, dar significado para a vida aqui na Terra. Essa vontade de contar foi apurada por meio da voz, mostrando-se uma maneira de expor e interpretar essas próprias relações humanas com o meio em que está inserido junto a outros sujeitos. A narrativa tornou-se um instrumento de perpetuação da humanidade, assim como toda e qualquer arte, as narrativas orais são fundamentais para um favorável crescimento pessoal e social, se a enxergarmos com os olhos da compreensão e levarmos em conta a realidade cultural. Dessa maneira, as narrativas das crianças precisam ser ouvidas como um instrumento que mostre ao outro o seu papel, a sua linguagem no processo de interação com o seu espaço. É por meio das narrativas que nos constituímos também como sujeitos sociais.

As produções culturais das crianças precisam ser apreendidas como forma de estar no mundo, de como são inseridas no meio e de como o meio interage com elas. Nesse sentido, tentar entender o caminho das produções de relações, intervenções, subjetividades e até mesmo de interpretação é tentar entender juntamente o grupo social, o espaço e o tempo como um todo, mas por um olhar sensível. 
Por esse rio que estamos embebidos, em se tratando da Amazônia, é que vamos em busca das crianças que por muito tempo estiveram apenas no papel de receptores de histórias, ouvintes, que Maria do constroem suas identidades a partir da convivência e interações Socorro Galvão com o outro, com a sua realidade, pois "os dados da história, como Simões

Cristiane

do Socorro

Gonçalves

Farias realidade empírica, pertencem à realidade histórica do indivíduo" (SIMMEL, 1983, p. 16). Sendo assim, são vivências dando enfoque às poéticas da oralidade, salientando a voz da criança narradora, por meio das histórias orais.

A criança aprende por meio da linguagem e interação com o outro, seja de maneira formal, na escola, ou por meio ditos "informais", em casa com a família, com os amigos. Dessa interação, vai montando seu próprio repertório: histórias ouvidas, histórias resultadas da sua própria experiência de vida, histórias que marcam, carregadas de traumas. Histórias de algo acontecido na escola, de suas brincadeiras, dos problemas familiares, dos seus anseios, das suas angústias, de um sonho da noite passada, de uma tarefa realizada, enfim, em diversas situações em que o ato de narrar é a ponte que transporta a criança para outros caminhos: a imaginação e a memória.

Aqui, em especial, elas constroem seus textos no momento em que estão fazendo o papel de ouvintes, e por alguns instantes tomando a palavra para complementar a narrativa do outro, no momento em que ouvem, já tomam para si aquela narrativa.

No decorrer das pesquisas em busca de teorias que orientassem para o estudo com crianças narradoras, percebemos que tal tema ainda é discutido a passos lentos dentro de diversas áreas do conhecimento, tendo em vista que, por muito tempo, a criança não era percebida como sujeito confiante de pesquisas.

Ao pesquisarmos em bancos de dados como o banco de teses e dissertações no Domínio Público, e do portal da Capes, na área de Letras, é perceptível um vasto volume de trabalhos direcionados aos adultos como narradores tradicionais. Em uma breve pesquisa nesses portais, constatou-se que trabalhos com as narrativas orais das crianças, são comuns na área de Educação, Psicologia e Antropologia. Ainda por cima, muitos pesquisam as narrativas orais contadas por adultos para as crianças e raros trabalhos acadêmicos que trazem a criança como narradora. Como nos ratifica Hartmann: 
A perspectiva de estudar a produção e a transmissão de narrativas orais que tem como sujeitos as crianças se não é, inteiramente nova, tem sido pouco explorada, [grifo meu] não apenas por pesquisadores das áreas de artes, como também das áreas afins como As narrativas antropologia, sociologia e educação. 0 crescimento do campo da orais e 0 antropologia da criança, da sociologia da infância e dos estudos imaginário da infância na educação, embora ainda não tenha modificado das crianças substancialmente esse quadro, já começa a delinear um camiribeirinhas nho fértil de investigação (HARTMANN, 2013, p. 53 [grifo meu]).

Os poucos trabalhos que trazem a criança como sujeito narrador, a criança narradora da sua própria experiência, é uma das preocupações da pesquisadora anteriormente citada: “o dossiê parte da constatação de que embora exista um vasto acervo de pesquisas e produções acadêmicas sobre narradores adultos e sobre histórias contadas para crianças, pouco ainda tem se tem enfocado a produção narrativa das crianças" (HARTMANN, 2015, p. 8 [grifos da autora]). ${ }^{2}$

Historicamente, percebemos uma "invisibilidade" HARTMANN (2015, p, 08), quando nos reportamos à criança. A pesquisadora continua a reflexão explicando que a "invisibilidade" pode partir do significado da palavra infância, etimologicamente oriunda do Latim; percebe-se que infans refere-se a "aquele que não fala" o que é "mudo". Contudo, aqui, enveredamos pelo conceito de criança, que também vem do Latim-creantia. $O$ vocábulo é particípio presente neutro plural de creare (criar, fazer, crescer), ou seja, o ser humano que cresce e tem capacidade de criar, em especial a criança que narra, produtora de sua própria narrativa, criativa.

Chevalier \& Gheerbrant referem a criança como símbolo da inocência, em outras palavras, o estado anterior ao pecado, aproximando-a ao estágio embrionário que leva à infância e, por sua vez, é símbolo de simplicidade e espontaneidade: "a criança é espontânea, tranquila, concentrada. Sem intenção ou pensamentos dissimulados" (Lao-tse, 55 comentado em Tchuang-tse, cap. 23) (CHEVALIER \& GHEERBRANT, 2012, p. 302). Becker se iguala ao falar em inocência e espontaneidade e

2 A autora refere-se ao dossiê sobre as narrativas orais infantis organizado pela Revista Boitatá $\mathrm{n}^{\circ}$ 20. A informação pode ser acessada em: http://revistaboitata. portaldepoeticasorais. inf. br/revista/edicao/ numero-20-semestre-jul-dez-2015. Acesso em: 09 de novembro de 2017. 
Maria do

Socorro Galvão

Simões

Cristiane

do Socorro

Gonçalves

Farias acrescenta de forma sucinta que a criança "também é símbolo do princípio e da plenitude das possibilidades" (BECKER, 1999, p. 77). É partindo dessas interpretações que este trabalho faz sua trilha.

Benjamin, ao falar sobre suas memórias, refere uma outra perspectiva por meio de seus olhos de infante. E percebe o quanto os adultos tomam decisões sobre o mundo das crianças. No entanto, os adultos, não percebem que elas os imitam, fazendo uso de seus objetos descartados, coisas mais simples, como restos de materiais: "assim, as crianças criam, elas próprias, o seu mundo e das coisas, um mundo pequeno dentro do grande mundo" (BENJAMIN, 1992, p. 46).

Nesse sentido, refletimos sobre a maneira como as crianças vivem o mundo das narrativas de tradição oral. o que nós adultos descartamos na hora de contar e as crianças (re)aproveitam? A criança é metáfora do poeta que vê na palavra a sua liquidez, pois é nessa fase da vida que o ser humano se sente mais liberto: "na nossa infância, o devaneio nos dava a liberdade", conforme Bachelard (2006, p. 95). Além disso, para Zumthor (2010), a relação das vozes ultrapassa algo, nos explica o quanto são poderosas e vão além da palavra essas vozes. Essas narrativas precisam ser ouvidas como um instrumento que mostre ao outro o seu papel, a sua linguagem no processo de interação com o seu espaço.

\section{As crianças das águas}

A criançare ferida neste trabalho vive na Amazônia, mais especificamente no município de Curralinho, na Ilha do Marajó, no Estado do Pará. A ilha está dividida em 13 distritos, entre os quais se encontra o município de Curralinho. Uma das mais intrigantes características dela é a diferença de territórios que há em sua extensão: "o dualismo geográfico é marcante; a área de campos distingue-se nitidamente da zona das matas, que cobre a maior parte - sudoeste" (MIRANDA NETO, 2005, p. 27). Essa diferença na natureza e nas relações do Homem para com o lugar fora observado também por Morais:

E como é natural, a desigualdade florística estabelece também a desigualdade na vida do homem; aqui vaqueiro e lá seringueiro. Enquanto este trabalha com a borracha, madeiras, fibras, óleos, resinas, aquele trabalha com o rebanho, couro e xarque. A montada do habitante da floresta é a canoa, enquanto que a do habitante do campo é o cavalo. (MORAIS, s/d, p, 36). 
A cidade está localizada na Costa Sul da Ilha de Marajó, na zona das matas, onde "a água barrenta dos dois braços do Amazonas dá um aspecto todo peculiar ao solo de suas margens; a exuberante mata de Igapó, cortada por inúmeros igarapés, paranás e furos, é o cenário mágico da fauna regional" (MIRANDA NETO, 2005, p. 30). Por ser uma cidade ribeirinha, banhada pelo Rio Pará, "este rio apresenta águas barrentas e turvas, ricas em sedimentos originários do seu rio fonte" ${ }^{3}$ e, rota para muitas embarcações, a cidade servia como ponto de parada obrigatória.

As narrativas orais eo imaginário das crianças ribeirinhas

Aqui mais em baixo, veio um pessoal chamado frade, metido a padre. Então eles vieram praí e fizeram um lugar pra eles ficarem repousando. Aí eles ficaram aí... Como a praia vai muito fora, não tinha como embarcar uma embarcação, então eles encontraram um canal acima do Maruaru e lá eles abriram e fizeram uma casa e um curral pra boi. E ia passando dois viajeiro e nunca tinham visto aquela casa ali, e disseram: -Mas rapaz, olha aquela casa, linda! -Olha aquele curral, lindo! Aí ficou Curralzinho, Curralinho! (Seu Duquinha, 2015).

Apesar dos indícios de fazendas no local, essa foi uma atividade econômica sem sucesso no local. Tempos depois de sua fundação, infelizmente a cidade não é um modelo de desenvolvimento. Entretanto, ainda tem nas águas uma forte fonte de renda. Muitas famílias sobrevi-

3 A informação pode ser acessada em: $h$ ttps://pt. wikipedia. org/wiki/Rio_Para. Acesso em: 09 de novembro de 2017.

4 A informação pode ser acessada em: https://cidades. ibge. gov. br/brasil/pa/curralinho/historico. Acesso em: 09 de novembro de 2017. 
Maria do

Socorro Galvão

Simões

Cristiane

do Socorro

Gonçalves

Farias

118

vem da pesca artesanal de camarão e de peixes. O extrativismo é outra atividade que voltou a fazer parte da economia de tantas outras famílias, principalmente a extração da semente do açaí.

Nesse sentido, a água é um elemento fundamental na vida de todos. Ainda mais para as crianças. 0 rio é brincalhão. As águas muitas vezes são leves, suspensas de problemas e de lamentos. Se toda a criança, desde o ventre de sua mãe, já tem intimidade com as águas, pois estão envoltas no líquido que as permitem viver, o que dizer das crianças que nascem dos ventres que se banham todos os dias nos rios? Para Cohn (2005, p. 14), "crianças existem em toda parte, e por isso podemos estudá-las comparando suas experiências e vivências; mas essas experiências e vivências são diferentes para cada lugar, e por isso temos que entendê-las em seu contexto sociocultural".

Bachelard (2013), metaforicamente, mostra a água como se fosse a mãe que envolve o filho nos braços e o embala, para explicar a importância das águas na vida do ser humano. A criança apresenta a inocência e a pureza associada às águas que apresentam frescor e, ao mesmo tempo, lhes reserva uma segurança. As águas aqui nesse momento são as águas calmas que embalam as crianças a se jogarem, literalmente, em seus leitos, realizando mergulhos muito profundos. As brincadeiras dentro e fora das águas são todas carregadas de simbolismo, e por isso "seremos menos capazes de entender o que elas fazem nessas brincadeiras se não entendermos a simbologia que as embasam, e essa simbologia extrapola o mundo das crianças" (COHN, 2005, p. 16). E são espaços como esses, das águas, das narrativas, imagens e imaginários, em que estão inseridas as crianças narradoras deste artigo.

\section{0 encontro: um breve relato de campo}

Trabalhar as narrativas orais das crianças surgiu a partir da dissertação de uma das autoras, na qual trabalhou-se com os velhos narradores ribeirinhos, em 2014, no programa de pós-graduação Linguagens e Saberes na Amazônia, pela Universidade Federal do Pará campus Bragança. $O$ objetivo da dissertação era fazer uma cartografia das narrativas ainda contadas ao longo do rio $\mathrm{Canaticu}^{5}$, rio pertencente ao município. 0 trabalho todo foi feito com mais de vinte narradores,

5 Rio pertencente ao município de Curralinho. 
no entanto, fez-se necessário o recorte tanto de narrativas, quanto de narradores. A dissertação ficou com 24 narrativas de 6 narradores cartografadas na comunidade da Calheira no baixo rio Canaticu.

Ao voltar ao material coletado durante o percurso da pesquisa, foram encontrados no caderno de campo breves relatos dos encontros com as crianças, além de dois áudios gravados com as vozes delas no momento da escuta das narrativas com os velhos. As participações surgiram de forma espontânea, sem provocação por parte da pesquisadora, a não ser pela curiosidade e atenção delas em relação às histórias contadas naquele instante.

Um destes áudios tem uma participação muito rápida, apenas complementa a voz do velho narrador, ao lembrar-lhe de detalhes da história contada. $\mathrm{O}$ avô explicou que ela já havia ouvido de seu pai aque-

As narrativas orais eo imaginário das crianças ribeirinhas la narrativa. No segundo áudio, de 3 minutos e 39 segundos, a outra criança, que estava perto de outro narrador, em outro encontro, conta duas narrativas na íntegra. É este segundo áudio que impulsiona esta escrita sobre as narrativas orais das crianças.

A dissertação anteriormente citada enveredou-se pela pesquisa qualitativa, a qual caracteriza-se pela coleta de dados junto às pessoas envolvidas no processo, mais especificamente a pesquisa participante. A caraterística basilar desta é o envolvimento e o reconhecimento do pesquisador com os sujeitos envolvidos. Ocasionalmente, mexe com a subjetividade, como percebemos na experiência de Brandão (2007, p. 12): “por outro lado a experiência de trabalho de campo tem uma dimensão muito intensa de subjetividade". Para o autor, essa intensidade acaba, por vezes, redefinindo o método da pesquisa: "a própria experiência do trabalho de campo redefiniu projetos, redefiniu hipóteses de trabalho, redefiniu abordagens metodológicas e assim por diante" (ibidem).

Apesar de não se tratar de um trabalho etnográfico, essa metodologia se fez necessária por conta do objetivo em traçar uma cartografia do que narravam os velhos ribeirinhos marajoaras. Sendo assim, se fez imprescindível a presença da pesquisadora, para que houvesse a confiança da comunidade, dos sujeitos pesquisados, confiança essa que só foi alcançada pelo tempo de interação, o qual foi de dois meses entre idas e vindas ao Lócus.

Como estratégia para a construção da cartografia das poéticas orais, foi utilizada a entrevista aberta, onde pedíamos que nos contassem suas histórias de infância, de trabalho, de família, enfim, relatos de 
vida. Em muitos casos não se fez necessário o direcionamento para as narrativas mitopoéticas, pois elas vinham imbricadas nessas histórias. Para dar-se conta dos registros das narrativas e das imagens, alguns

Maria do

Socorro Galvão

Simões

Cristiane

do Socorro

Gonçalves

Farias equipamentos foram necessários, como: gravador, máquina fotográfica e um caderno de campo.

\section{0 retorno ao material}

A partir deste momento, voltamos ao caderno de campo e às gravações. No percurso inicial da pesquisa, o primeiro narrador que concordou em conversar foi "seu" Souza. Foram três encontros com mais de seis horas de gravações no total. No segundo dia, encontramos uma criança sentada na escada de madeira que dá acesso à porta do narrador. Como no dia anterior, "Seu" Souza contava suas histórias e a menina ouvia tudo com atenção. Em um determinado momento, ele pediu licença para resolver um problema e se ausentou. Ficamos a sós na sala - a criança e a pesquisadora. Aquela falou seu nome, idade e o que fazia ali, disse que era parente do entrevistado. De repente, pediu para ver a máquina fotográfica, curiosa, arriscou algumas fotos. Em seguida, pediu uma fotografia sua. Fez a pose mais terna que podia. Perguntou o porquê daquelas histórias e para que precisaríamos delas.

Depois de explicado o motivo de ouvirmos "seu" Souza, ela, meio encabulada, disse tinha uma história e gostaria de contar:

- Pode contar! ${ }^{6}$

- Mas não vai ligar isso? Perguntou a criança.

Quando o narrador saiu, desligamos o gravador. Ela, atenciosa, fez-nos lembrar. Assim que ligamos, passou por uma visível timidez, depois de alguns segundos, começou a narrar. Foram pouco mais de três minutos de gravação nos quais contou duas narrativas. Logo mais, "seu" Souza retornou, e a gravação com a criança foi encerrada. Depois daquele dia, nunca mais a reencontramos.

Nesses parágrafos seguintes, iremos relatar um fato interessante acontecido com uma das pesquisadoras, Cristiane Farias, envolvendo os áudios no momento da transcrição. A pesquisadora ouvia a história com o auxílio da caixa de som do computador, em volume alto, para não correr o risco de perder o entendimento de nenhuma palavra. Escrevia

6 Para dar um destaque à primeira voz infantil, coloco em itálico. As narrativas subsequentes da criança narradora estão com espaçamento simples, itálico e recuo de $1 \mathrm{~cm}$ de ambo os lados. 
direto em uma folha de papel e, de vez em quando, era inevitável a pausa. A história girava em torno de uma moça, a mãe da criança, que havia engravidado, ao mesmo tempo, de um boto e de um homem, e o fruto dessa dupla união acabou nascendo boto da cintura para baixo e gente da cintura para cima. A pesquisadora ouvia e transcrevia sem notar o movimento ao seu redor. Acresce que sua filha, de seis anos de idade, que brincava por perto se aproxima e fala:

- Mãe, então sereia existe!

As narrativas orais eo imaginário das crianças

Como assim, filha?

- Se a mãe dela teve um filho metade gente, metade peixe, é sereia! Então sereia existe! Porque sereia é assim!

A filha da pesquisadora olha e sai com a certeza e a leveza de uma criança que não precisa de tantas explicações e razões, simplesmente é! O impacto é inevitável, pois não imaginaria que ela estaria ouvindo e prestando atenção àquela história. Ainda por cima, traz um outro prisma para a narrativa: sereia existe de fato.

O que nos parece, é que a criança duvidava da existência de sereias. No entanto, ao pronunciar o advérbio "então", nesse contexto toma a forma de elemento conclusivo e tira de si a dúvida de não existência de sereias no mundo, portanto, a possibilidade de existência agora para ela é certeza.

A criança, naturalmente, permeia a aura de que nos fala Walter Benjamin, ao ser citado por Maffesoli (2001, p. 75): “o imaginário permanece uma dimensão ambiental, uma matriz, uma atmosfera, aquilo que Walter Benjamin chama de aura. O imaginário é uma força social de ordem espiritual, uma construção mental, que se mantém ambígua, perceptível, mas não quantificável", ou seja, ele simplesmente está aí, não podemos mensurar. E para ela, a partir da história que ouve, não precisa quantificar, as sereias existem.

\section{As narrativas}

Na sequência, são apresentadas as reproduções das narrativas apresentadas pela criança de aproximadamente 11 anos, com a qual conversamos no intervalo da entrevista com o "seu" Souza, em fevereiro de 2015, quando da coleta de dados para a dissertação de mestrado, conforme explanado anteriormente. Como forma de elucidar a etapa da transcrição do oral para o escrito, esclarecemos que o nosso foco era as narrativas em si, e não questões pertinentes à linguística. Para tanto, 
Maria do

Socorro Galvão

Simões

Cristiane

do Socorro

Gonçalves

Farias

não fizemos correções no que tange à gramática, as variantes estão da maneira como a criança apresentou. As pausas feitas pela criança são representadas por meio das reticências, as quais marcam a suspensão das suas falas. Outro ponto utilizado é o ponto de exclamação, o qual se aproxima da demonstração de sua emoção ao contar a história.

\section{A Cobra Grande}

Em relação à narrativa da Cobra Grande, os registros podem variar, dependendo da fonte de onde são ouvidas. No entanto, a vertente mais conhecida é a da mulher que dá à luz duas cobras, que em seguida são batizadas e jogadas no rio, uma cobra macho e uma cobra fêmea, uma boa e outra má. Também podemos encontrar narrativas da Cobra Grande em que se mostra como um lindo navio muito iluminado, muito luminoso, que some em instantes. Da Cobra Grande que abre furos e igarapés por conta do seu tamanho. A Cobra que tenta afundar embarcações, entre tantas outras ${ }^{7}$.

Aqui, a criança que estava junto à pesquisadora e também escutava as histórias de "seu" Souza, no momento em que ele se ausenta, diz saber duas histórias que aconteceram com sua própria mãe. 0 pedido para que gravássemos veio espontâneo e começa com a narrativa da cobra:

\section{Narrativa contada pela criança}

A mamãe tava no casco e a cobra buiou por baixo... Aí, ela teve o neném e a cobra. Os enfermeiros de lá queriam matar a cobra! Aí, ela soltou... Passou um tempo a cobra cresceu. Aí... Ela tava atravessada no igarapé, o igarapé grande, na ilha da Mucura. Aí... Ela apareceu pra mamãe... Monstra! Chega ela chupava o casco pra trás, e a mamãe:

- Remem, meus filhos, remem! Olhem essa Cobra Grande!

Aí, de noite ela veio pra mamãe:

- Desculpa, mãe! Era eu que tava me apresentando!

Mas ela disse pra mamãe no sonho dela noutro dia, que era pra ela tirar um pouco de leite do peito dela pra ela jogar em cima da cabeça que ela desencantava. Era uma menina linda! A mamãe não teve coragem... Eu disse pra mamãe:

- Se fosse minha filha eu ia desencantar!

7 Essas vertentes são provenientes da experiência de escuta com os velhos narradores na Vila Calheira no Rio Canaticu, Curralinho-Marajó, que resultou no livro: Imaginário da ilha: o Marajó das histórias e memórias (FARIAS, 2017, no prelo). 
Eu já falei pra mamãe... Quando nós for pra ilha pra ela fazer isso. Ao menos pra desencantar a mana do fundo! Ela é grandona... Dessa grossura (abre os braços) atravessava o igarapé, chega o rabo dela ficava enrolado, a cabeça dela ia lá no alto. Ainda falei:

As narrativas

- Mãe! Faz isso pra desencantar a mana!

- Eu não vou fazer! Ela ainda me morde! (Dá uma risadinha)

orais eo

- Deixe de ser medrosa... Faz isso! Ela disse que vai pensar...

imaginário

das crianças

ribeirinhas

Nessa história, a criança nos mostra algumas características próprias das narrativas de Cobra Grande, como dito antes: a gravidez da mãe, o rio, o igarapé, a grandiosidade do animal, o sonho. Entretanto, ela nos mostra que sabe o momento exato da gravidez: o instante em que a cobra passa por debaixo da canoa em que a mãe estava. Na hora de dar à luz, não nos aparece a figura da parteira e sim a de um enfermeiro, "de lá", o pronome demonstrativo reforça o local em que tudo aconteceu.

Passado um tempo, esse que a criança não sabe o quanto, "passou um tempo", mas suficiente para que a cobra tivesse crescido. Para ela, a cobra está tão grande que sente a necessidade de dimensionar igualando seu tamanho à largura de um igarapé, “ igarapé grande” pois ela era muito grande "monstra", ou seja, maior do que possamos imaginar, se assemelha a um monstro.

O sonho é uma caraterística comum. É o elo entre a filha cobra e a mãe, sendo que esta não teve coragem de desencantar aquela. A partir daqui, podemos perceber o carinho da criança narradora pela suposta irmã cobra, repreendendo a mãe da narrativa por sua covardia e termina a narrativa de forma inusitada: a cobra pode ser desencantada a qualquer momento, pois a mãe ainda vai pensar na possibilidade do desencantamento de sua irmã.

Percebemos que a história em questão não termina como costumamos ouvir, a cobra não dobra seu encanto. Para a criança há a possibilidade de desencantamento, uma continuidade possível da narrativa para um outro possível final, pois a mãe ainda irá pensar no assunto, dando esperanças à criança.

Benjamim (1993, p. 221) afirma que o narrador é um bom conselheiro: "Ele sabe dar conselhos". Sabemos que é por conta da experiência de vida, pela sabedoria que adquire com elas. Acresce que a criança, neste contexto, apesar de não ter tantos anos de experiência de vida como tem um velho, aconselha a mãe a ter coragem de agir e desencan- 
tar sua irmã, e essa não a escutou. Para Bachelard (2006, p. 97), a "criança enxerga longe, a criança enxerga belo. O devaneio voltado para a criança nos restitui à beleza das imagens primeiras". São as belezas que

Maria do

Socorro Galvão

Simões

Cristiane

do Socorro

Gonçalves

Farias perdemos quando adultos, em um mundo que nos tira por completo a cor das coisas ao nosso redor, mas que as crianças conseguem enxergar.

\section{O Boto}

o boto é um animal que, desde sua origem, carrega simbologias. Muito comum nas águas doces, as histórias envolvendo-o são narrativas em que é muito comum acontecer a metamorfose. A narrativa mais recorrente do Boto, peixe pertencente à família dos cetáceos, é o animal que também está presente nas narrativas ribeirinhas, sua aparição, na maioria das vezes, é a figura do conquistador, do rapaz bonito, com vestimentas brancas, que adentra uma festa e acaba por encantar as moças. A moça que ele conquista fica apaixonada e grávida do Boto que some nas águas.

Em uma das variantes, o boto transforma-se em homem e aproveita a ausência do marido que sai para pescar à noite para encantar a mulher que, na maioria das vezes, está de resguardo, com criança pequena. De acordo com as narrativas, a intenção do Boto é manter relação sexual com a mulher ou raptar o recém-nascido ${ }^{8}$. As narrativas envolvendo boto são bem comuns em comunidades que vivem às margens dos rios. Acredita-se aqui na possível transformação dos seres não humanos em humanos, para demostrar a maneira como os homens enxergam o espaço em que estão inseridos.

A narrativa a seguir, do Boto, faz parte também do áudio da criança que escutava as histórias de "seu" Souza. Antes de começar a gravar, a criança disse que sabia duas histórias. Entretanto, pareceu esquecer a segunda. Por este motivo, na narrativa a seguir, a pesquisadora instiga a criança com perguntas. As perguntas estão com a mesma fonte do corpo do texto, mas a história da criança continua em itálico, para dar mais destaque.

Então, pergunto a ela sobre a história do boto que falou antes de gravarmos:

8 Esses relatos são provenientes da pesquisa de campo de umas das pesquisadoras no momento da feitura da dissertação: Um rio de memórias, um rio de histórias: um estudo sobre o imaginário da vila Calheira no rio Canaticu-Curralinho-Marajó-Pá. UFPA-2016 


\section{Narrativa contada pela criança}

E a história do Boto?

o boto? Tá aí pelo fundo!

Como foi?

As narrativas

o Boto passou por debaixo do casco, aí a mamãe já ficou grávida. Ela orais e o tava grávida do meu pai. imaginário Ela já estava grávida de seu pai? Já. Aí ela tava grávida. Aí, o boto passou e nasceu: pra cá pra baixo Boto das crianças e pra cima era do papai, gente! Aí ela soltou! Eu falei pra ela soltar isso! Era meu ir... (nesse momento ela para, pensa e continua) um piqueno?! Não sei se era menino ou menina! Esse veio no sonho?

Não. Só a cobra!

A circunstância da gravidez da mãe da criança nessa narrativa foi muito parecida com a história da Cobra Grande, mas agora a mãe já estava grávida de seu marido quando o Boto passa novamente por baixo de sua canoa. Há casos de interdito em que a relação física não se consuma, sendo suficiente a proximidade entre o animal. É o que a criança nos relata aqui, não houve a relação física direta.

A mãe tem no seu ventre alguma coisa que não é aceito pela criança, porque percebemos que nessa narrativa ela não consegue chamá-lo de irmão. No momento em que iria pronunciar a palavra irmão, ela substitui por "piqueno". Essa palavra, no contexto da pesquisa, é usada para nomear sujeitos dos quais não temos intimidade alguma, não se faz nem questão de saber o nome. Do mesmo modo, ao denominá-lo de "isso" "Eu falei para ela soltar isso", percebemos que ela não demonstra nem um sentimento de carinho pelo suposto irmão, diferente do que demonstrou ter na narrativa da Cobra Grande. A criança narradora nos traz a história de uma criança que nasce metade ser humano e metade Boto. Foi essa narrativa em questão que chamou a atenção da filha da pesquisadora, ao concluir que se poderia ser sereia, já que era metade humano e metade peixe.

A narradora também dá um conselho, mas este é para que a mãe o solte no rio, para deixar ir embora. A história do Boto foi contada com o mínimo de detalhes e palavras, parecia que queria terminar o quanto antes. Parecia que tinha um desgosto face a essa narrativa.

9 Aqui a criança usa o termo se referindo ao que ela diz ser filho do Boto e do pai. 


\section{Considerações finais}

Por conta do propósito de dar destaque à narrativa da criança ribeirinha e, concomitantemente, de não se tratar de um trabalho compara-

Maria do

Socorro Galvão

Simões

Cristiane

do Socorro

Gonçalves

Farias tivo, este não trouxe outros registros escritos de histórias com as mesmas temáticas analisadas, não somente de narradores tradicionais, mas também de estudiosos na área das narrativas de tradição oral.

Contudo, as narrativas contadas pela criança compõem paisagens que envolvem o imaginário dessa região da Amazônia, onde narrativas de Botos e Cobras Grandes fascinam e ao mesmo tempo amedrontam. Durante o percurso para esse trabalho, apesar de termos ouvido aqui apenas uma criança, percebemos o imaginário compartilhado por um grupo social, no qual a criança está inserida.

Para Maffesoli (2001, p. 76), o imaginário faz parte de um grupo, e não é individual, "o imaginário é um estado de espírito de um grupo, de um país, de um estado, de uma comunidade, etc. O imaginário estabelece um vínculo. É um cimento social. Logo, se o imaginário liga, une numa atmosfera, não pode ser individual". As narrativas orais emanam lembranças de que muito marcou sua vida. A sabedoria adquirida de sua própria experiência de vida é deixada para o ouvinte por meio da voz.

Para Zumthor (1993, p. 09-139), essa voz "é querer dizer e vontade de existência, lugar de uma ausência que, nela e transforma em presença" e continua "as vozes cotidianas dispersam as palavras no leito do tempo, ali esmigalham o real".

E essas vozes narradoras que sentem a necessidade de existência, como nos diz Zumthor (2010), é que nos possibilitam pensar na presença das vozes das crianças, para então entendermos como essas crianças se situam no mundo em que vivem. "É assim, em parte, que se enriquecem e se transformam as tradições" (ZUMTHOR, 2010, p. 258).

Para isso, faz-se necessário ouvir. É o que está faltando nesse mundo que cresce em um ritmo desacelerado. Temos que voltar a ouvir para (re)aprender a viver o verdadeiro tempo. 0 tempo de tudo e o tempo para tudo. 0 tempo da piracema, o tempo da desova do camarão, o tempo de debulhar, o tempo da roça. O tempo da enchente. O tempo da vazante. O tempo da preamar. O tempo da reponta. O tempo do conto e o tempo da escuta. O tempo da voz das crianças. 


\section{REFERÊNCIAS}

BACHELARD, Gaston. A poética do devaneio. Traduzido por A. P. Danesi. Revisão de tradução A. M. Mouzat, M. Laranjeira. $2^{a}$ ed. São Paulo: Martins Fontes, 2006.

As narrativas

orais eo imaginário

A água e os sonhos: ensaio sobre a imaginação da matéria. Traduzido por A. P. Danesi. $2^{\text {a }}$ ed. São Paulo: Editora WMF Martins Fontes, 2013.

BECKER, Udo. Dicionário de Símbolos. Traduzido por E. Royer. São Paulo: Paulus, 1999 - coleção dicionários.

BENJAMIN, Walter. Rua de Sentido Único e Infância em Berlim por volta de 1900. Traduzido por C. M. Rodrigues. Lisboa: Relógio D'Água Editores, 1992.

. O narrador. Considerações sobre a obra de Nicolai Lescov. In: Obras escolhidas. 6ª ed. Vol. I, São Paulo: Brasiliense, 1993.

BOSI, Ecléa. Memória e sociedade: Lembranças dos velhos. $3^{a}$ ed. São Paulo: Companhia das Letras, 1994.

BRANDÃO, Carlos de Rodrigues. Reflexões de como fazer trabalho de campo. Revista Sociedade e Cultura, V. 10, N. 1, jan/jun. p. 11-27.

CHEVALIER, Jean. Dicionário de Símbolos: mitos sonhos, costumes, gestos, formas, figuras, cores, números. 26ª ed. Rio de Janeiro: José Olímpio, 2012.

COHN, Clarice. Antropologia da criança. $2^{\mathrm{a}}$ Ed. Rio de Janeiro: Zahar, 2005.

FARIAS, Cristiane do S. Gonçalves. Um Rio de memórias, um Rio de histórias: um estudo sobre o imaginário da Vila Calheira-Canaticu-Curralinho-Marajó-Pá. 164f. Dissertação (Mestrado em Letras). Universidade Federal do Pará-Campus Bragança-Pá, 2016. . Imaginário da ilha: o Marajó das histórias e memórias. Curitiba: Appris Editora, 2017 (no prelo). 
HARTMANN, Luciana. Medo e encantamento em narrativas orais contadas por crianças. Cerrados. Revista de pós-graduação em Literatura, 2013, p. 50-67.

Maria do

Socorro Galvão

Simões

Cristiane

do Socorro

Gonçalves

Farias

128
Equilibristas, viajantes, princesas e poetas: performances orais e escritas de crianças narradoras. Revista Boitatá. Londrina № 20. jul-dez. 2015. p. 48/67.

LOUREIRO, João de Jesus Paes. Cultura Amazônica: uma poética do imaginário. Belém: Cejup. 1995.

MAFFESOLI, Michel. O imaginário é uma realidade. Revista FAMECOS. Porto Alegre. № 15. Agosto de 2001, quadrimestral.

MORAES, Raymundo. Anfiteatro Amazônico. São Paulo, Cayeiras, Rio de Janeiro: Melhoramentos, s. d.

MIRANDA NETO, Manoel José de. Marajó: desafio da Amazônia - Aspectos da reação e modelos exógenos de desenvolvimento. Belém: EDUFPA. 2005.

SIMMEL, Georg. O estrangeiro. In: Sociologia. Evaristo de Moraes Filho (org.). Traduzido por C. A. Pavanelli. São Paulo: Ática, 1983.

VELÔSO, Thelma Maria Grisi. Pesquisando Fontes Orais em busca da subjetividade. In: Oralidade e subjetividade: Os meandros infinitos da memória. Campina Grande: EDUEP, 2005.

ZUMTHOR, Paul. A letra e a voz: A "literatura" medieval. Traduzido por A. Pinheiro, J. P. Ferreira. São Paulo: Companhia das Letras, 1993. . Introdução à Poesia Oral. Traduzido por J. P. Ferreira, M. L. D. Pochat, M. I. Almeida. Belo Horizonte: UGMG. 2010.

- Recebido em abril / 2017

- Aceite em junho / 2017 